\title{
Immunophenotyping in leukemia and its diagnostic significance
}

\author{
S.B. Kresno*, S.H. Haryanto*, A.S. Kosasih*, A. Muthalib**, D. Atmakusumah**
}

\begin{abstract}
Abstrak
Identifikasi petanda permukaan sel yang dikenal sebagai kelompok antigen diferensiasi (clusters of differentiation antigens, CD) dapat digunakan untuk mengklasifikasi dan subklasifikasi leukemia. Walaupun antigen yang sama juga diekspresikan pada permukaan sel normal, fenotip pada permukaan sel ganas pada umumnya diekspresikan secara abnormal dan seringkali diekspresikan asinkron atau dalam kombinasi yang tidak lazim dijumpai pada sel-sel darah atau sumsum tulang normal. Ekspresi antigen secara abnormal ini dihubungkan dengan respons terapeutik yang buruk dan ketahanan hidup yang pendek. Penentuan petanda permukaan sebagai pelengkap pemeriksaan morfologi dan sitokimia dapat meningkatkan kemampuan untuk menentukan karakteristik keganasan hematologi. Dalam makalah ini akan dibahas tinjauan pustaka mengenai makna diagnostik pemeriksaan imunofenotip pada leukemia disertai ilustrasi pengalaman pemeriksaan ini di Rumah Sakit Kanker Dharmais. Data dari 225 pasien yang telah mengalami pemeriksaan hematologi lengkap termasuk morfologi, sitokimia dan pemeriksaan imunofenotip dikumpulkan antara tahun 1994-2001 dan dianalisis. Berdasarkan pemerikssan morfologi dan sitokimia diagnosis leukemia mielositik akut (AML) dan leukemia limfositik akut (ALL) ditegakkan masing-masing pada 51,1\% dan 48,9\% pasien. Berdasarkan pemeriksaan imunofenotip AML dijumpai pada 49,0\%, sedangkan ALL dapat dikelompokkan dalam 4,9\% pre-B ALL, 18,7\% B-ALL dan 14,7\% T-ALL. Jumlah kasus yang menunjukkan antigen dengan kombinasi tidak lazim atau "cross lineage" dijumpai pada 12,7\%. Makna prognostik kasus dengan ekspresi antigen abnormal ini masih harus ditelaah, tetapi sebagian dari kasus tersebut ternyata memberikan respons yang kurang baik terhadap terapi. Pemeriksaan imunofenotip merupakan sarana untuk: 1) membedakan klon leukemik dari klon normal; 2) menentukan jalur perkembangan lasal-usul dan maturasi sel ; 3) mengidentifikasi ekspresi abnormal dari antigen permukaan; 4) mendapatkan informasi lebih banyak yang diperlukan untuk menentukan diagnosis dan prognosis leukemia dibanding metode baku. (Med J Indones 2004; 13: 195-202)
\end{abstract}

\begin{abstract}
The identification of cell surface markers, defined as clusters of differentiation antigens (CD's) could be used to classify and sub-classify leukemia. Although the same antigens are expressed on normal cells, the phenotype on malignant cells are aberrantly and frequently asynchronously expressed and may be present in combinations not observed in normal blood or bone marrow. Aberrant expression of surface antigens corresponds with poor therapeutic response and short survival. Additional surface marker analysis complementary to morphologic evaluation and cytochemical staining has greatly improved our ability to characterize hematologic malignancies. A review and illustration on the diagnostic significance of immunophenotyping in leukemia will be presented. Data from 225 patients having complete assessments including morphology, cytochemistry and immunophenotyping in the period of 1994-2001 were collected and analyzed. Based on morphologic evaluation and cytochemistry, the diagnosis of acute myeloid leukemia and acute lymphoblastic leukemia were established in 51,1\% and 48,9\% of cases, respectively. Based on immunophenotyping AML was found in 49,0\% of the cases. ALL could be classified into 4,9\% pre-B-ALL, 18,7\% B-ALL, and 14,7\% T-ALL. Cases expressing cross-lineage antigens were found in $12,7 \%$. The prognostic significance of these aberrant expression of antigens for those cases has yet to be established but some of the cases responded poorly to therapy. Immunophenotyping provides the tool to: 1) distinguish normal from clonal populations of leukemic cells; 2) define lineage and reveal the stage of maturation; 3) identify inappropriate expression of lineage associated antigens; 4) provides more informations to establish diagnosis and prognosis compared to standard methods. (Med J Indones 2004; 13: 195-202)
\end{abstract}

Keywords: Immunophenotyping, clusters of differentiation antigens, lineage associated antigens.

* Department of Clinical Pathology, Faculty of Medicine University of Indonesia/Dharmais National Cancer Center Hospital, Jakarta, Indonesia

** Division of Medical Oncology, Faculty of Medicine University of Indonesia/Dharmais National Cancer Center Hospital, Jakarta, Indonesia
Rapid and precise diagnosis of leukemias is critical so that apropriate treatment can be initiated without delay. With the development of new treatment modalities it is also essential to have accurate prognostic factors. The most widely accepted and applied classification of leukemias is based on morphological and cytochemical criteria, proposed by the FAB group. ${ }^{1}$ However, a fact 
is that there are no major prognostic differences among the FAB-subgroups, and we still don't know why some patients in the same subgroup do much better or worse than others. With the discovery of highly spesific antibodies and molecular probes which define a cell phenotype and its biologic behaviour, it is currently known that although leukemic cells appear cytologically similar, their surface and intracellular markers may differ considerably ${ }^{2,3}$ and this might explain the differences in patients outcome. In immunologic analysis of acute myeloid leukemias, discrepancies frequently exist between morphology cytochemistry and immunophenotyping. These discrepancies may include cases in which morphology and cytochemistry are concordant, but the cells devoid of lineage specific antigens. This usually occurs in poorly differentiated leukemias. Also, morphology and cytochemistry may agree, but the MoAbs detect a discordant cell-line. Lastly, the morphology and cytochemistry may be discordant, but the immunologic markers agree with one of them and permit the correct assessment of cell lineage. These findings reemphasize the multifaceted unified approach essential in acute leukemia diagnosis.

Recently WHO has proposed a new classification of leukemia and lymphoma which include pathologic findings, i.e. morphology, immunophenotyping, cytogenetics, and clinical features, but this is not prevalent yet. The proposed WHO classification of AML includes traditional FAB categories of disease as well as additional disease type that correlate with specific cytogenetic findings and AML associated with myelodisplasia. There seem to be substantial overlap between disease groups in the WHO proposal. It has been proposed that pathologic classification for AML should include disease type that correlate with specific cytogenetic translocation and can be recognized reliably by morphologic evaluation and immunophenotyping and that incorporate the importance of associated myelodysplastic changes. ${ }^{4}$

For this publication we will focus only on the diagnostic significance of immunophenotyping in acute leukemia.

\section{The application of cell surface markers}

The discovery of monoclonal antibodies (MoAbs) that define cell surface antigens, have led to important insights into leukocyte differentiation and the cellular origin of leukemia. Leukemic cells express a variety of leukocyte differentiation antigens which reflex commitments to the myeloid or lymphoid lineage as well as levels of maturation It is now possible to define stages of human lymphocyte and granulocyte differentiation precisely using those highly specific MoAbs. ${ }^{1,5,6,7}$ As a results of The International Workshops on Human Leukocyte Differentiation Antigens, groups of MoAbs that recognize the same antigen have been identified and are referred to as cluster designation or cluster of differention antigens (CD's). ${ }^{8}$ These CD's are currently used to define cell lineage as well as stage of maturation . Loken et $\mathrm{al}^{9}$ divided normal marrow B cells into four discrete developmental stages by cell membrane expression of CD34, CD19, HLA-DR, CD10, TdT and CD22. The most immature B cells (stage I) express CD34, CD19, HLA-DR, CD10 and TdT; stage II express HLA-DR, CD10 and CD19; stage III had HLA-DR, CD10, CD19, CD20 and sIg; stage IV had HLA-DR, CD20 and CD22. The same investigators found a high incidence of "asynchronous" combinations of B-cell antigens in B-ALL, such as co-expression of CD34 and CD22. This finding suggests that ALL may not accurately represents cells arrested at the stage where the leukemogenic events occurred. $^{10,11}$ Similar to the classification of B-ALL based on developmental stages of the cells, T-ALL are classified according to the stages of thymocyte maturation. ${ }^{4}$ The most immature T-cells (stage I) expressed CD34, CD7, CD2, cCD3 and TdT. Stage II had CD7, CD2, cCD3, CD5, CD4+CD8, CD10, CD1 and TdT. The most mature T-cells (stage III) expressed $\mathrm{CD} 7, \mathrm{CD} 2, \mathrm{cCD} 3, \mathrm{CD} 5, \mathrm{CD} 4$ or $\mathrm{CD} 8$ and sometimes TdT.

The differentiation within the monomieloid lineage is complicated by the presence of four cell lineage, i.e. monocyte, neutrophil, eosinophil and basophil. The normal monomieloid lineage is characterized by its typical light scattering properties and the presence of a particular sequence of antigens i.e. CD33, CD11b, CD15, CD14. Monomieloid cells not yet differentiated into either the granulocytic or monocytic lineage co-expressed the CD34 and CD33 antigen and had relatively low orthogonal light scattering signals. Maturation towards the monocytic lineage is characterized by a loss of CD34 antigen, acquisition of CD11b followed by CD15 and CD14 accompanied by specific changes of light scattering properties. Differentiation towards the neutrophilic lineage is characterized by a loss of CD34 antigen, acquisition of CD15 antigen accompanied with a decreased of the CD33 antigen density and the subsequent acquisition of the CD11b and CD14 antigens. Neoplastic cells are clearly distinguishable from the normal cells based on the abnormal expression of normal antigens. ${ }^{12}$ 
The widespread application of MoAbs to identify the origin and degree of differentiation of neoplastic cells has currently become an essential component in the study of hematologic malignancy. But in spite of their high specificity, it is not suitable to use one single $\mathrm{MoAb}$ for distinguishing neoplastic from normal hemopoetic cells because the same antigens found on malignant cells are also present on their normal counterpart. In leukemias, however, cell-surface antigen expression often does not follow the normal maturation pathways, resulting in aberrant expression of cell-surface antigens. In addition, leukocyte antigens may be expressed on malignant cells with abnormal density or exceeding certain arbitrary level, or in combinations that normally are not observed in peripheral blood and bone marrow. These aberrant combinations, referred to as asynchronous development, are often unique to individual cases and need to be identified at presentation. These combinations can later be exploited to identify residual leukemia and be used to assess both the efficacy of treatment and the ocurrence of early relapse. Such abnormal density and phenotypic combinations can be identified by multidimensional flowcytometry applying double or triple color staining techniques performed with MoAbs conjugated to different fluorochromes. Aberrant expression of any combination of normal antigens in concordance with light scattering characterization defines a leukemic cell population which distincts from normal. ${ }^{13-16}$ Flowcytometry is adjunctive for the diagnosis of AML and may be the only way to confirm a diagnosis of M0 and M7 because cytochemical stains may be uninformative. ${ }^{17}$

\section{Immunophenotyping in leukemia}

Immunophenotyping studies suggest that acute leukemias might express unexpected heterogeneity not identifiable by morphological evaluation. Many studies revealed that malignant transformation sometimes results in both aberrant and unstable cellular phenotypes. Such unstable phenotypes are most likely the result of aberrant gene transcription, which occurs as a result of the leukemogenic process. Lineage heterogeneity has therefore been explained on the basis of this malignant transformation of a progenitor cell capable of development along either myeloid or lymphoid pathways. ${ }^{10}$ It has also become evident that especially in B-lineage ALL, immunophenotypic subgroups mirror a high degree of genotypic diversity and that multiple distinct molecular pathways are involved in ALL pathogenesis. ${ }^{18}$ This information has been useful to achieve a more precise distinction of biologically and clinically relevant subgroups. Therefore, in addition to the morphological and cytochemical analysis by light microscopy, immunophenotyping has currently become a powerful tool in characterizing and subclassifying leukemia. ${ }^{5}$ and will help understand the patient's disease characteristics that may ultimately predict response to therapy. ${ }^{2,19-22}$

Immunophenotyping is also useful in situation in which adequate tissue is not available for definitive diagnosis in B-cell lymphoma. ${ }^{23}$ Rizati et $\mathrm{al}^{24}$ disclosed that expression of CD117 and CD11b in bone marrow can differentiate acute promyelositic leukemia (APL) from recovering benign myeloid proliferation. The work of Wuchter et al ${ }^{19}$ revealed that although CD133 and CD90 expression analysis is not helpful for lineage determination in acute leukemia immunophenotyping, MoAb AC133 (CD133) may be an informative marker for the detection and further characterization of immature AML cells as well as pre-B ALL cells with MLL gene translocation by flowcytometry.

Cornelo et $\mathrm{al}^{25}$ used immunophenotypic analysis to diagnose myelodysplastic syndrome (MDS). Their work disclosed that in MDS, the majority of CD34+ cells are already committed to the myeloid lineage. MDS patients showed an increased proportion of monocytic cells with a decreased percentage of neutrophil lineage, leading to a lower neutrophil / monocyte ratio. Maturational arrest in the monocytic but not in the neutrophil differentiation pathway were observed. In refractory anemia with excess blast in transformation (RAER-t), such blockades mainly occurred during the earliest stages of differentiation, but in the other MDS subtype they occurred in later stages. Phenotypic aberrations occurred in $90 \%$ of patients and a high proportion of cases showed $>2$ aberrations.

Several groups of investigators have proposed several criterias to classify acute leukemias, which appeared to have good diagnostic accuracy, ${ }^{26}$ and a consensus on two colour immunophenotyping using primary and secondary panel is shown on Table 2 and 3. 
Table 1. Antigens (CD's) frequently analyzed in the immunophenotyping of hematologic malignancies

\begin{tabular}{ll}
\hline Antigen with broad expression & \\
\hline Panmyeloid antigen & CD13, CD33, CDw65, MPO \\
Pan-B cell antigen & $\begin{array}{l}\text { cyCD22, CD19, cyCD79a } \\
\text { cyCD3, CD2, CD7, CD5 }\end{array}$ \\
$\begin{array}{l}\text { Pan-T cell antigen } \\
\text { Antigen associated with maturation } \\
\text { Immaturity }\end{array}$ & TdT, CD34, HLA-DR \\
$\begin{array}{l}\text { Ag with lineage specific and maturation dependent } \\
\text { expression }\end{array}$ & \\
$\begin{array}{l}\text { Myeloid cells } \\
\text { B-cells } \\
\text { T-cells }\end{array}$ & CD14, CD15, glycoprotein A, CD41, CD61 \\
NK cells & CD20, CD23, FMC7, cIgM, sIg \\
\hline
\end{tabular}

Table 2. Consensus on two colour immunophenotyping in leukemia using primary panel

\begin{tabular}{cc}
\hline FITC & R-PE \\
\hline CD45 & CD3 \\
MPO & Lactoferrin \\
CCD3 & cCD22 \\
CD7 & CD33 \\
CDw65 & CD19 \\
HLADR & CD13 \\
IgM & CD10 \\
Ig $\kappa$ & CD19 \\
IG $\lambda$ & CD19 \\
\hline
\end{tabular}

Table 3. Secondary panel in leukemia

\begin{tabular}{lcc}
\hline & FITC & R-PE \\
\hline In AML & CD45 & Glycophorin A \\
& CD14 & CD15 \\
& CD61 & CD64 \\
& CD34 & CD14 \\
& CDw65 & CD56 \\
In B-ALL & CD2 & CD13 \\
& CD41 & CD42b \\
In T-ALL & CD34 & CD22 \\
& CD24 & CD5 \\
& CD4 & CD8 \\
\hline
\end{tabular}

Complementing conventional morphologic and cytochemistry evaluation, immunophenotyping has increased our understanding of these neoplasms and has allow insights into their classification based on their lineage and differentiation. The introduction of immunophenotyping along with flowcytometric technology which provides rapid multidimensional cellular analysis, have enabled the identification and characterization of surface components of the leukemic cells with better objectivity and has therefore contributed substantial additional information for the establishment of the diagnosis $2,3,5,14,27,28$ 
The choice of MoAbs as diagnostic tool for leukemias depends on the suspected diagnosis and differential diagnosis based on the morphologic evaluations. As mentioned earlier, reactivity with only one antibody is not sufficient in determining cell lineage in the diagnosis of acute leukemia. These MoAbs can help determine the lineage of leukemic cells when used in combination. Furthermore, one should never make a diagnosis based on immunophenotyping alone: the results must be interpreted in conjunction with morphologic features. ${ }^{6}$

\section{Immunophenotyping for the detection of residual leukemia}

At diagnosis, patients with acute leukemia may have a total of approximately $10^{12}$ malignant cells. The disease is considered to be in complete remission when fewer than $5 \%$ of the cells in the bone marrow are morphologically normal blast. However, these patients may still have as many as $10^{10}$ neoplastic cells not detectable by conventional methods. Detection of genetic abnormalities by the PCR method has been used to detect minimal residual disease (MRD) with a very high sensitivity $\left(1: 10^{6}\right)$. However, false positive PCR results derived from contaminating traces of DNA occurred frequently, and should therefore be considered. These errors should be avoided by using clone specific probes and by careful manipulation and processing of samples and the use of multiple controls. ${ }^{29}$

The work of Sausville et $\mathrm{al}^{30}$ showed that flowcytometry is superior to PCR for detecting MRD of hairy cell leukemia. It was more sensitive and more specific and permits quantitation of tumor cell number. Monitoring of MRD become increasingly important in the risk-adapted management of patients with AML. Multiparameter flow cytometry has shown accuracy and sensitivity in the quantification of MRD levels with independent prognostic impact. ${ }^{31-33}$ Up to $80 \%$ of all patients can be monitored by flowcytometry ${ }^{34}$ One of the strategies of detecting MRD by immunologic methods takes advantages of the observation that leukocyte markers may be found on malignant cells in combinations that are not normally found in peripheral blood or bone marrow. ${ }^{10,16,32,35}$ Once such a combination has been identified, thereafter the bone marrow can be screened for persistence of leukemic cells that display that differentiation antigen combination. The persistence of such cells is indicative of MRD, and is predictive of shortened remission duration, whereas the loss of such cells is associated with a prolonged remission duration. ${ }^{14}$

An example of abnormal combination of surface antigens is CD33 and CD19. Immature myeloid antigens such as CD33 are never found on a cell on which lymphoid antigens are found, such as CD19. In most cases of T-ALL, the lymphoblasts express TdT in association with CD3, CD5 or CD1. Although normally expressed by developing $\mathrm{T}$ cells, such phenotypes are usually not found outside the thymus. A combination of CD34 and CD56 is found in 20\% of childhood AML. ${ }^{29}$ Once such a combination has been identified, thereafter the marrow can be screened for persistence of leukemic cells that display the same antigen combination. When bone marrow samples of the same patients are analysed after chemotherapy in hematological remission, the absence or presence of cells with the "leukemia associated" phenotypes should give clinically relevant information about the probable absence of disease or the emergence of relapse. In addition, changes in phenotypes may accompany chemotherapy, suggesting the appearance of variant or new clones. ${ }^{2}$ The application of multidimensional flowcytometry and the use of carefully selected multiple combinations of MoAbs appeared to be helpful in the detection of residual leukemia with a sensitivity of reaching $1: 10^{6}$, but a sensitivity of $1: 10^{4}$ is more realistic. ${ }^{14,35}$ In most cases, intensity of antigen expression may also help in distinguishing leukemic cells from the rare normal progenitors expressing the same phenotypes. By relying on the cells "light scattering properties" in addition to their immunophenotype, one can identify different subsets of bone marrow cells not found on normal marrow. ${ }^{29,36}$

Table 4 indicates immunophenotypic combinations used to study MRD in patients with acute leukemia. ${ }^{29}$

\section{Immunophenotyping as a diagnostic and prognostic tool of leukemia : Dharmais Cancer Center Experience}

The diagnosis of acute leukemia in our institution were routinely made on the basis of light microscopic examination of peripheral blood and bone marrow aspiration. The morphological appearance of blasts was classified in accordance with the criteria of the FAB standard. In addition, the following cytochemical reactions using standard procedures were performed: myeloperoxidase (MPO), Sudan black B (SBB) and nonspecific esterase (NSE) reactions. 
Table 4. Immunophenotypic combinations used to study MRD (Campana et al) ${ }^{29}$

\begin{tabular}{|c|c|c|c|}
\hline Disease & Phenotype & $\begin{array}{c}\text { Frequency } \\
(\%) \#\end{array}$ & $\begin{array}{l}\text { Freq in normal BM } \\
(\% \text { pos cells } \pm \text { SD })\end{array}$ \\
\hline \multirow[t]{6}{*}{ B-ALL* } & TdT-CD10 (or CD19-CD34)/CD13 & 7 & $0.02 \pm 0.01$ \\
\hline & TdT-CD10 (or CD19-CD34)/CD33 & 8 & $0.03 \pm 0.02$ \\
\hline & TdT-CD10 (or CD19-CD34) /CDw65 & 7 & $0.02 \pm 0.01$ \\
\hline & TdT-CD10 (or CD19-CD34) /CD21 & 10 & $0.02 \quad 0.01$ \\
\hline & TdT-CD10 (or CD19-CD34)/CD56 & 9 & $<0.01$ \\
\hline & $\mathrm{TdT} / \mathrm{c} \mu / \mathrm{CD} 34$ & 14 & $0.03 \pm 0.01$ \\
\hline T-ALL & TdT/cCD3 & 90 & $<0.01$ \\
\hline \multirow[t]{2}{*}{ AML } & CD34/CD56 & 20 & $<0.01$ \\
\hline & CDw65/CD34/TdT & 15 & $<0.01$ \\
\hline
\end{tabular}

*Approximately $35 \%$ of cases have at least one leukemia-associated phenotype

\# Greater than $10 \%$ positive leukemic lymphoblast

\section{Immunophenotyping}

It was not possible to analyze all cases admitted to our institution for their phenotypes due to financial problems, but on a substantial number of cases immunophenotyping could be performed on bone marrow aspirates and or peripheral blood. For peripheral blood samples to be eligible for analysis, the proportion of blast cells must be at least 30\%. Phenotypic evaluations were performed using leukemia phenotyping kit (Becton Dickinson) which include MoAbs against CD45, CD3, CD5, CD7, CD10, CD19, CD20, CD22, CD13, CD33 and HLA-DR. When necessary, additional MoAbs such as CD34, CD14, CD15, CD4, CD8, CD16/CD56 and immunoglobulin light chains ( $\kappa$ and $\lambda$ ) were included. This panel had been selected to simplify the test, which was necessary due to financial limitations, yet clinically adequate to characterize leukemias in our institution. CD13, CD14 and CD15 were particularly selected, because more than one study claimed that those markers have significant prognostic associations in AML. ${ }^{3,26}$

Immunofluorescence analysis was performed by multidimensional flowcytometry on a FACScan instrument (Becton Dickinson Immunocytometry System) equipped with an Argon Laser-beam tuned to $488 \mathrm{~nm}$ emission. Cell surface antigen expression and the light scattering signals of the cells passing the sensing area were measured simultaneously. Calibration beads (Calibrite, $\mathrm{BD}$ ) were routinely used for monitoring and optimizing the instruments setting. Data acquisition was performed with Cellquest software (BD). Co-expression of different lymphoid and mieloid antigens were confirmed by dual color analysis using appropriate pairs of MoAbs conjugated to fluorescein isothiocyanate (FITC) and phycoerythrin (PE) or peridinin-chlorophyl-protein (PerCP).

Leukemic cells from fresh EDTA-anticoagulated bone marrow aspirates or peripheral blood samples were isolated by Ficoll-Hypaque (Pharmacia) density gradient centrifugation. The white layer consisting mononuclear cells were washed twice with PBS before staining. The cells were incubated with above mentioned panel of MoAbs in such a manner that cells in each tube were stained with a pair of appropriate labelled MoAbs. Stained cells were then analyzed on the FACScan instrument. A number of 20.000 ungated list mode events were collected and an appropriate blast cell gate based on a combination of forward and side scatter were selected. Cells within the most appropriate blast cell gate were analyzed for their phenotypes considering their clonality and fluorescence intensity. With the availability of flowcytometry using multidimensional analysis it is possible to demonstrate aberrant features of antigen expression and that individual blasts from a leukemic patients can express lymphoid and mieloid characteristics simultaneously. Antigen co-expression was diagnosed if the blasts disclosed simultaneously expression of more than one different lineage associated antigen.

\section{Phenotypic profile}

Data were available from 225 patients treated between March 1994 and December 2001, having complete laboratory examinations including cytomorphology, cytochemistry and immunophenotyping. The diagnosis based on conventional FAB method i.e. morphology and cytochemical staining, were compared to the diagnosis based on their phenotypes (Table 5). 
Table 5. Distribution of leukemias by standard method and immunophenotyping

\begin{tabular}{cc|ccccc}
\hline \multicolumn{2}{c|}{ FAB } & & \multicolumn{4}{c}{ IMMUNOPHENOTYPING } \\
\hline AML & ALL & AML & PRE-B & B-ALL & T-ALL & Cross \\
& & & & & & lineage \\
\hline 115 & 110 & 111 & 11 & 42 & 32 & 29 \\
$(51,1 \%)$ & $(48,9 \%)$ & $(49,0 \%)$ & $(4,9 \%)$ & $(18,7 \%)$ & $(14,7 \%)$ & $(12,7 \%)$ \\
\hline
\end{tabular}

Some discrepancies were observed between the results of standard method and immunophenotyping, probably due to the inability of conventional methods to diagnose doubtful cases. These findings in our institution reemphasized that a multifaceted unified approach in the diagnosis of acute leukemia is essential. Based on morphologic evaluation, AML and ALL were established consecutively in $51,1 \%$ and $48,9 \%$ of the cases. Based on immunophenotype analysis, AML was found in $49,0 \%$ of the cases, whereas ALL cases could be divided into $4,9 \%$ pre-B-ALL, $18,7 \%$ B-ALL and 14,7 \% T-ALL. Cases coexpressing more than one unexpected lineage associated antigen i.e. AML expressing lymphoid markers or vice-versa, were observed in $12,7 \%$ of the cases. We considered these cases as a separate subgroup which might probably have a different prognostic property, and for the moment we classify them as acute leukemia with co-expression of antigens of different lineage (cross lineage) or AMLL as suggested by earlier studies. ${ }^{34,37}$ The prognostic value of these aberrant expression of antigens for these cases has yet to be established, but earlier studies revealed the association of mixed lineage leukemia with poorer clinical response or shorter survival. $^{27,38,39,40}$

These data suggest that immunophenotyping was a very useful tool to classify and sub-classify leukemia, complementary to morphologic evaluation and cytochemical staining. In certain cases immunophenotyping was superior to standard methods, particularly when diagnosis by standard methods was unclear, and where more informations on prognostic factors were required to predict treatment outcome.

Another application of immunophenotyping in our institution was to identify and quantify CD34+ stemcells in peripheral blood after mobilization with hemopoetic growth factors to support peripheral blood stemcell transplantation program. The CD34+ cell count was used to decide when to obtain mobilized stemcells from the blood. The count predicts the yield of progenitor cells that can be collected by leukapheresis necessary for peripheral blood stemcell transplantation to patients undergoing high dose chemotherapy. Although the number of cases until now is limited, this procedure seems to be promising to improve cancer management in our institution.

\section{CONCLUSION}

Although morphologic evaluation and cytochemical staining still play important roles in the diagnosis and classification of leukemias, additional surface marker analysis of the leukemic cells in our institution has greatly improved our ability to characterize hematologic malignancies. Immunophenotyping provides the tools to: 1) distinguish normal from clonal populations of leukemic cells; 2) define lineage and reveal the stage of differentiation; 3) identify inappropriate expression of lineage associated antigens or mixed lineage leukemia; 4) identify and quantify stemcells necessary to predict the yield of cells that should be collected for peripheral blood stemcell transplantation. 5) detect MRD in cases expressing aberrant phenotypes.

\section{REFERENCES}

1. Bennett JM, Catovsky D, Daniel MT, et al. Proposals for the classification of the acute leukemias. Br J Hematol 1976; 33: 451-8

2. Ludwig WD, Rieder $\mathrm{H}$, Bartram $\mathrm{CR}$, et al. Immunophenotypic and genotypic features, clinical characteristics and treatment outcome of adult pro-B acute lymphoblastic leukemia: results of the German Multicenter trials GMALL 03/87 and 04/89. Blood 1998; 92: 1898-909

3. Bradstock K, Matthews J, Benson E, et al. Prognostic value of immunophenotyping in acute leukemia. Blood 1994; 84: $1220-5$

4. Arba DA. Realistic pathologic classification of AML. Am J Clin Pathol 2001; 115: 552-60

5. Jennings CD and Foon KA. Recent advances in flowcytometry: Application to the diagnosis of hematologic malignancies. Blood 1997: 99(8): 2863-92

6. Huh YO. Surface markers in acute and chronic leukemia and non-Hodgkin's lymphoma. The Cancer Bull 1993; 45: 78-85 
7. Ginsberg $\mathrm{CH}$, Kagan J, Liang JC, Stass SA. Recent advances in the diagnosis of acute leukemia. The Cancer Bull 1993; 45: 64-9

8. Knapp W (ed) Leukocyte typing IV. White cell differentiation antigens. Oxford, Oxford Univ Press 1989

9. Loken MR, Shah VO, Dattilio KL, Civin CI. Flowcytometric analysis of human bone marrow II: Normal B lymphocyte development. Blood 1987; 70: 1316-24

10. Kersey JH. Fifty years of studies of the biology and therapy of childhood leukemia. Blood 1997; 90: 4243-51

11. Launder TM, Bray RA, Stempora L, et al. Lymphoid associated antigen expression by acute myeloid leukemia AJCP. 1996; 106: 185-91

12. Terstappen LWMM, Loken MR. Myeloid cell differentiation in normal bone marrow and acute myeloid leukemia assessed by multidimensional flowcytometry. An Cellular Pathol 1990; 2: 229-34

13. Borowitz MJ, Shuster J, Carroll AJ, et al. Prognostic significance of fluorescence intensity of surface marker expression in childhood B-precursor acute lymphoblastic leukemia. A Pediatric Oncology Group Study. Blood, 1997; 89: $3960-6$

14. Campana D, Behm FG. Leukemia immunophenotyping: uses for establishing diagnosis, predicting outcome and assessing treatment response. In: Whittaker JA (ed) Leukemia ( $2^{\text {nd }}$ ed) London, Blackwell Sc; 1992: 203-11

15. Terstappen LWMM, Konemann S, Safford M, et al. Flowcytometric characterization of acute myeloid leukemia. Part I. Significance of light scattering properties. Leukemia 1991; 5(4): 315-321

16. Dong HY, Corczyca W, Liu Z et al. B cell lymphoma with co-expression of CD5 and CD10. Am J Clin Pathol 2003; 119: $218-30$

17. Seiter K. Acute myelogenous leukemia. Available at. http//www emedicine.com/ med/topic34 2001

18. Cline MJ. The molecular basis of leukemia. N Engl J Med 1994; 330:328-38

19. Wuchter C, Ratei R, Spahn G, et al. Impact of CD133 (AC 133) and CD90 expression analysis for acute leukemia immunophenotyping. Available at: http//www. haematologica.it/2001

20. Munoz L, Aventin A, Villamor $\mathrm{N}$, et al. Immunophenotypic findings in acute myeloid leukemia with FLT3 internal tandem duplication. Haematologica 2003; 88: $637-41$

21. Jilani I, Estey E, Huk Y, et al. Differences in CD33 intensity between various myeloid neoplasms. Am J Clin Pathol 2002; 118: 560-6

22. Li S, Eshleman JR, Borowitz MJ. Lack of surface immunoglobulin light chin expression by flowcytometric immunophenotyping can help diagnose peripheral B cell lymphoma. Am J Clin Pathol 2002; 118: 229-34

23. Xu Y, Mc Kenna RW, Kroft SH. Assessment of CD10 in the diagnosis of small B cell lymphoma: a multiparameter flowcytometric study. Am J Clin Pathol 2002; 117: 291-300

24. Rizzati EG, Garcia AB, Portieres FI, et al. Expression of CD117 and CD11b in bone marrow can differentiate acute promyelocytic leukemia from recovering benign myeloid proliferation. Am J Clin Pathol 2002; 118: 31-7
25. Connielo del Camzo M, Fernandez ME, Lopez A, et al. Immunophenotypic analysis of myelodysplastic syndrome. Haematologica 2003; 88: 402-7

26. Van der Schoot EC. The immunological characterization of malignant cells in acute myeloid leukemia. Acad Thesis, Univ of Amsterdam, 1989

27. Ludwig WD, Raghavachar A, Thiel E. Immunophenotyping classification of acute lymphoblastic leukemia. Clin Haematol 1994; 7: 235-9

28. Dworzak MN, Fritsch G, Froschi G, et al. Four-color flowcytometric investigation of terminal deoxynucleotidyl transferase positive lymphoid precursors in pediatric bone marrow: CD79a expression precedes CD19 in early B-cell oncogeny. Blood 1998; 92: 3203-9

29. Campana D, Pui CH. Detection of minimal residual disease in acute leukemia: methodologic advances and clinical significance. Blood 1995; 85: 1416-34

30. Sausville JE, Salloum RG, Sorbara L, et al. MRD detection in hairy cell leukemia. Comparison of flowcytometric immunophenotyping with clonal analysis using consensus primer PCR for the heavy chain gene. Am J Clin Pathol 2003; 119: 213-7

31. Vidriales MF, Orfao AF, San-Miguel JF. Immunologic monitoring in adults with acute lymphoblastic leukemia. Current Oncol Rep 2003; 5: 413-8

32. Kern W, Danhauser-Riedl S, Ratei E, et al. Detection of minimal residual disease in unselected patients with acute myeloid leukemia using multiparameter flowcytometry to define leukemia-associated immunophenotype and determine their frequencies in normal bone marrow. Haematologica 2003; 88: 646-53

33. Munoz L, Nomdedeu JF, Villaor N, et al. Acute myeloid leukemia with MLL rearranegements: clinicobaiological features, prognostic impact and value of flowcytometry in the detection of residual leukemic cells. Leukemia 2003; 17: $76-82$

34. Kern W, Schnittger S. Monitoring of acute myeloid leukemia by flowcytometry. Curr Oncol Rep. 2003; 5(5): 405-12

35. Stass S, Mirro J. Unexpected heterogeneity in acute leukemia: Mixed lineage and lineage switch. Human Pathol 1985; 16: 864-6

36. MacDonald AP, Janossy G, Ivory K, et al. Leukemia associated changes identified by quantitative flowcytometry IV. CD34 overexpression in acute myelogenous leukemia M2 with t $(8 ; 21)$. Blood 1996; 87: 1162-9

37. Drexler HG, Thiel E, Ludwig W. Acute myeloid leukemias expressing lymphoid associated antigens: Diagnostic incidence and prognostic significance. Leukemia 1993; 7: 489-98

38. Hurwitz CA, Mirro J, Stass SA. Mixed lineage leukemia and asynchronous antigen expression. Hematol Oncol Clin North Am 1990; 4: 767-94

39. Campana D. Applications of cytometry to study acute leukemia: In vitro determination of drug sensitivity and detection of minimal residual disease. Cytometry, 1994; 18 68-73

40. Holowiecka BS, Jagoda K, Krzemien S, et al. Prognostic significance of abnormal immunophenotypes in adult acute leukemia. Intl J Hematol 1996; 64 (suppl 1): S171 